\title{
DIURNAL CYCLE OF GLOMERULAR FILTRATION RATE AND SODIUM AND CHLORIDE EXCRETION DURING RE- SPONSES TO ALTERED SALT AND WATER BALANCE IN MAN *
}

\author{
By LAURENCE G. WESSON, JR. AND DAVID P. LAULER $\dagger$ \\ (From the Department of Medicine, New York University School of Medicine, \\ New York, N. Y.)
}

(Submitted for publication May 12, 1961 ; accepted July 20, 1961 )

A diurnal cycle in volume and composition of the urine in man has long been recognized. For the most part, excretion of water and electrolytes is lowest toward the end of the sleeping period and is greatest at some time during the hours of normal wakefulness. Descriptions of the diurnal cycle of sodium chloride excretion have been published by Völker (1), Campbell and Webster (2), Kleitman (3), Simpson (4-6), Norn (7), Manchester (8), Barbour and co-workers (9), Borst and de Vries (10), Gerritzen (11), Stanbury and Thomson (12), Azérad, Lestradet, Reinberg and Gatha (13), Lewis and Lobban (14-16), Payne and de Wardener (17) and Doe, Vennes and Flink (18) and in other studies noted below. The cycle does not depend upon meals, activity or salt content of the diet, since it persists during fasting or evenly spaced feeding $(7,12,19-21)$, during complete rest $(2,12,21)$ and on sodium restricted or supplemented diets $(7,12)$. Although the cycle can be disturbed, but not abolished, by sleeplessness $(3,5)$ and is reversed in night workers $(5,7)$, the normal 24-hour cycle is retained, at least temporarily, in subjects on 12-hour sleep-activity cycles (22) and during the first 24 to 72 hours after acute reversal of the sleep rhythm $(3,7$, 19). The excretory cycle can be partially dissociated from the sleep-activity rhythm in subjects whose daily routine is organized around a 22 or 27 hour day, but the degree of dissociation between the two rhythms seldom exceeds 2 hours $(15,16)$.

Changes in body fluid content such as may attend variations in salt and water intake are fol-

\footnotetext{
* Supported by grants from the American Heart Association and by Grant $\mathrm{H}-2172$ from the United States Public Health Service.

$\uparrow$ Research Fellow of the American Heart Association; present address, Peter Bent Brigham Hospital, Boston, Mass.
}

lowed by alterations in the mean daily excretion rate of salt and water which, directionally, are such as to minimize the disturbance in body composition. Although these alterations may be described in several ways, they represent, in effect, changes in the level, amplitude or form of the diurnal cycle. The mechanisms that determine the character of the diurnal excretory cycle and alter the cycle after changes in body fluid balance are largely inferential but appear to involve changes both in the rate of extrarenal secretion of humoral agents which modify renal tubular transport of electrolytes and water, and in the rate of glomerular filtration of salt and water. Studies relating to a possible role of filtration rate in these mechanisms have been reviewed recently (23).

Glomerular filtration rate exhibits a diurnal cycle, increasing by day and decreasing by night, which tends to parallel the sodium chloride excretory cycle $(12,24)$. In subjects with congestive heart failure or cirrhosis, in whom the excretory cycle is frequently reversed, the filtrationrate cycle is generally reversed also (25-27). Correspondingly, filtration rate is generally elevated above control values after chronic loading with saline (28) or after chronic water retention obligated by vasopressin (Pitressin tannate) injections $(29,30)$ and is depressed in volunteer subjects or patients on low salt diets (31-36). In subjects or patients in whom salt retention is induced by steroid (usually deoxycorticosterone) administration. filtration rate is generally increased after several days of salt accumulation and at the time that control rate of salt excretion has been regained $(37-41)$.

From none of these studies, however, is information available concerning the diurnal cycle of glomerular filtration rate during states of altered 
fluid balance, the changes in this cycle during the transition from one to another state, and correlation (or lack of it ) between changing filtration rate and changing sodium chloride excretion during the transition phase. The studies reported here were undertaken to examine these questions.

\section{METHODS}

The experiments were performed on 3 healthy male subjects. Because of their familiarity with the techniques and theory involved, all three are considered trained subjects. A dietary history was obtained prior to an experiment. A standard single day's menu, closely approximating the usual diet, was then prepared with the collaboration of the subject. This menu was repeated each day of the study, subject only to modification of the salt or water content. One to two days before beginning the clearances, the subject was admitted to a private hospital room or to a metabolic study unit to become adjusted to the diet and to the routine of restricted activity, regular urine collection and other procedures. When the protocol was functioning smoothly, clearance measurements were begun.

Priming quantities of inulin and $p$-aminohippurate $(\mathrm{PAH})$ were calculated to produce plasma concentrations of 30 and $1.5 \mathrm{mg}$ per $100 \mathrm{ml}$, respectively. A sustaining solution of 5 per cent inulin and 1.6 per cent $\mathrm{PAH}$ was injected intravenously at 0.6 to $0.7 \mathrm{ml}$ per minute by a Sigmamotor pump through an indwelling plastic catheter. This solution, although supersaturated with respect to inulin, will remain clear for weeks if care is taken to avoid seeding with solid inulin. PAH was omitted from some experiments where avoidance of the additional sodium load in the PAH was considered more important than measurement of PAH clearance. When PAH and inulin were infused simultaneously, they were added to distilled water, the PAH contributing sufficient osmotic pressure to prevent hemolysis. ${ }^{1}$ When inulin was infused alone, it was added to 5 per cent glucose. In some experiments powdered, refined inulin, ${ }^{2}$ refiltered before use (43), was dissolved in the appropriate vehicle. In other experiments, commercial, ampouled inulin (Warner-Chilcott) was employed. Since this inulin is prepared in saline, a quantity sufficient for 24 hours' infusion contains $2.5 \mathrm{~g}$ of sodium chloride and an amount of salt approximating this quantity was removed from the patient's diet. The infusion was delivered to the subject through a 10- to 12-foot length of small-bore Tygon tubing which permitted free ambulation within the confines of the study room. Although the subjects were relatively inactive, they were not confined to bed. Clearance periods were generally of 3 hours'

${ }_{1} \mathrm{PAH}$ and glucose, when together in solution, form a compound which yields anomalous clearance values (42).

2 Kindly supplied by the General Diagnostics Division, Warner-Chilcott Corp. duration, but 4-hour periods were employed during sleep in some studies. Inulin clearance was not calculated for periods (see figures) in which large changes in plasma inulin concentration occurred as the result of disturbances of the infusion. Average rate of change in plasma inulin concentration in the remaining periods did not exceed 10 per cent per hour. Urine specimens were routinely collected by voluntary voiding, with the exception of the final clearance period in one experiment (Figure 2) when difficulty in urination required catheterization. Blood specimens were drawn at 3-hour intervals through an indwelling catheter contralateral to the infusion catheter and at either the midpoint or the end of the periods. In some studies, $15-\mathrm{ml}$ specimens were drawn, and no attempt was made to restore the drawn blood. In other studies, in which $25-\mathrm{ml}$ specimens were drawn, the packed cells were suspended in saline and reinjected to minimize possible renal function changes arising from cumulative blood loss. Under such conditions no measurable change in hematocrit could be detected, but approximately $8 \mathrm{~g}$ of plasma proteins was removed each day. Weight and temperature were measured frequently; blood pressure and pulse were not measured routinely. Infusions and consecutive clearance periods were continued for 2 to 5 days. Further pertinent methodologic details will be noted during discussion of the individual experiments.

Inulin concentration was measured as follows. To 1 $\mathrm{ml}$ each of plasma and urine samples in 25-ml Erlenmeyer flasks was added $8 \mathrm{ml}$ of a 1.0 per cent aqueous suspension of washed yeast. The flasks were lightly stoppered and allowed to stand overnight. One $\mathrm{ml}$ each of 10 per cent zinc sulfate and $0.75 \mathrm{~N}$ sodium hydroxide (Somogyi precipitation) was added, the flasks were shaken, allowed to stand a few minutes, and the centrifuged supernatant collected by decantation. Inulin in the plasma filtrates and appropriately diluted urine filtrates was measured colorimetrically by the method of Roe, Epstein and Goldstein (44) as modified by Schreiner (45). The above method of yeasting regularly removed 95 per cent of a $200 \mathrm{mg}$ per $100 \mathrm{ml}$ glucose or fructose solution. A plasma blank was obtained by similarly treating $1 \mathrm{ml}$ of inulin-free plasma. Thus measured, the plasma blank is equivalent to about $2 \mathrm{mg}$ per $100 \mathrm{ml}$ plasma inulin and is extremely constant, exhibiting no discernible variation pre- and postprandially or from patient to patient. Most of the color of the blank arises from the yeast. The urine blank, although of nearly the same absolute magnitude as the plasma blank, is so small as a fraction of total urine inulin that it is generally ignored. Yeast blanks and yeast "hematocrits" were not measured. All specimens were routinely analyzed in duplicate de novo, and on different days. Determinations on each of the two separate analyses were done in triplicate. A third analysis was performed if the $U / P$ ratios of the first two analyses failed to agree within 5 per cent. Chloride was measured by the method of Van Slyke and Hiller (46), and sodium by flame photometry. PAH clearances and plasma concentrations, and excretion rates 
of potassium, calcium, magnesium, and phosphate will be reported in subsequent papers.

\section{RESULTS}

Normal diurnal cycle. Diurnal cycles of filtration rate, and plasma concentrations and urinary excretion of sodium and chloride in inactive, healthy subjects on routine diets are shown in the control days of Figures 1-5. The average diurnal cycle in Subject R.S., calculated by averaging for each portion of the cycle the values observed in 5 control days, is shown in Figure 6. The contour of the excretion curves is similar to those reported in other studies. A regular observation in this subject was a brief but marked decrease in excretion coincident with the evening meal and possibly arising from gastrointestinal secretion. Plasma sodium was generally lower during the day but the difference between day and night was small. Chloride concentration varied more widely than did sodium in this subject, usually exhibiting decreases coincident with the morning and evening

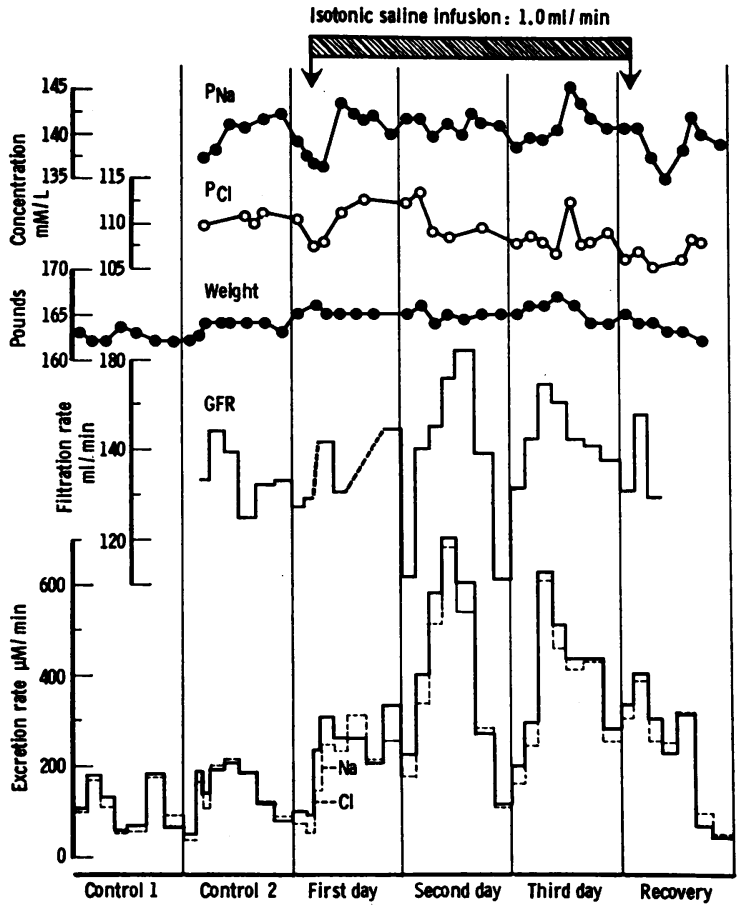

Fig. 1. DiURnal CyCle of FILTRATION RATE AND SODIUM AND CHLORIDE EXCRETION BEFORE AND DURING ISOTONIC SAline infusion. Subject K.B.: age 23 ; wt 74 kg ; ht $173 \mathrm{~cm}$. In this and the following figures, a "day" is 7 a.m. to 7 a.m.

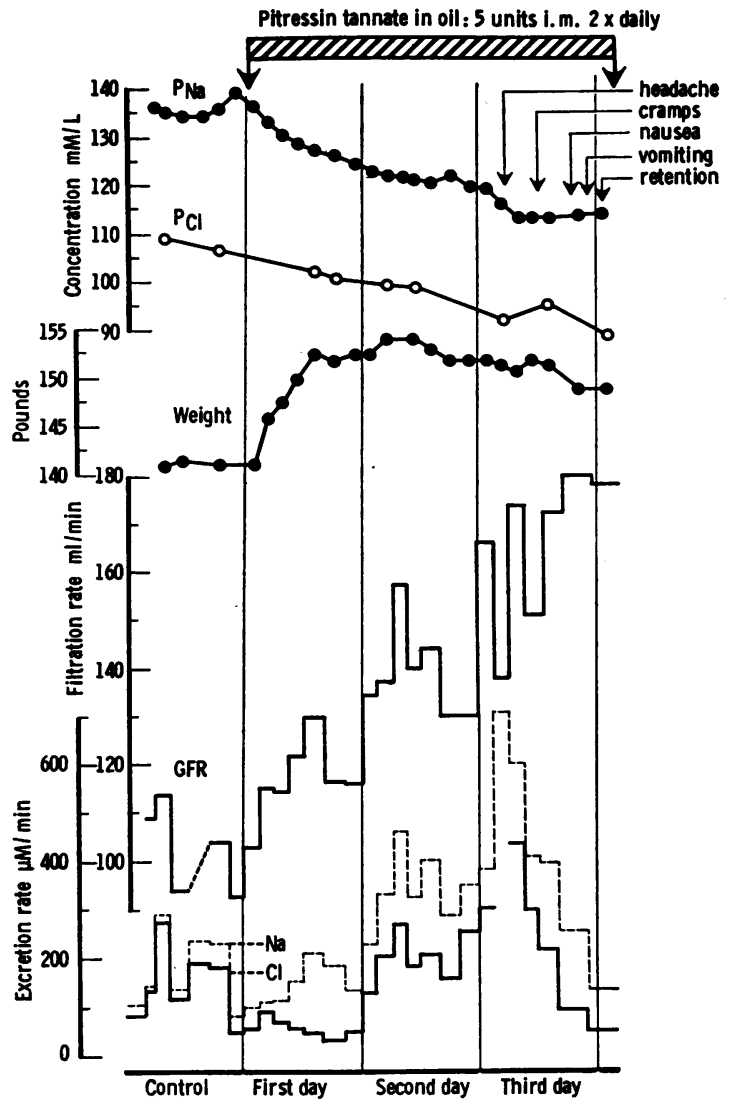

Fig. 2. Diurnal cyCle of Filtration Rate and soDIUM AND CHLORIDE EXCRETION BEFORE AND DURING CHRONIC WATER LOADING SUSTAINED BY VASOPRESSIN INJECTIONS. Para-aminohippurate was infused throughout. Subject R.S. : age 29; wt $65 \mathrm{~kg}$; ht $174 \mathrm{~cm}$.

meals and also possibly related to gastrointestinal secretion. The amplitude of the filtration rate cycle is approximately 20 per cent of the 24-hour mean value in the average cycle. The average amplitude of the separate cycles, however, is 26.5 per cent, and the true amplitude, discoverable by progressively shortening the clearance periods, may well exceed 30 per cent of the 24 -hour mean rate.

Diurnal cycle during saline infusion. The diurnal cycles of $\mathrm{NaCl}$ excretion and glomerular filtration before and during infusion of isotonic saline are shown in Figure 1. The continuous infusion provided additional salt intake of about $13 \mathrm{~g}$ per 24 hours. During the first infusion day, salt excretion increased moderately, the increase being accomplished for the most part by suppression of the normal nocturnal decrease in excretion rate. 
Interruptions of the inulin infusion prevented measurement of clearance during several periods, but values in the remaining periods of the first day suggest that daytime inulin clearance did not increase. An increase in plasma chloride concentration at this time may have contributed to the increase in excretion. During the second and third infusion days, diurnal cycles of both excretion and filtration were resumed. As compared with the control, the excretory cycle showed an increase both in minimum (base line) and in the amplitude, together with a narrowing of the nocturnal depression. The filtration rate cycle showed an increase both in amplitude and in the 24-hour mean, the latter rising to 135 and $145 \mathrm{ml}$ per minute on the second and third days, compared with a control value of $128 \mathrm{ml}$ per minute (Table I). The values attained during the brief nocturnal minima, however, were not significantly different (two cycles) from that in the control.

Diurnal cycle during chronic water loading. The diurnal cycles of $\mathrm{NaCl}$ excretion and glomeru-

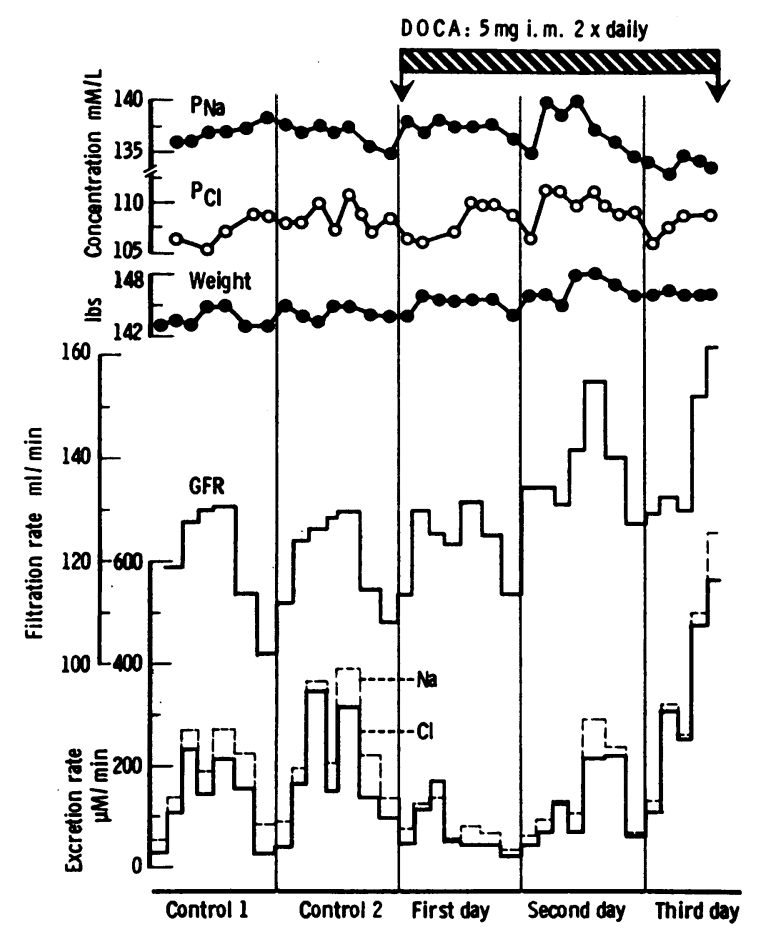

Fig. 3. Diurnal CyCle of Filtration RATE AND SODILM AND CHLORIDE EXCRETION BEFORE AND DURING SODIUM CHLORIDE RETENTION INDUCED BY DEOXYCORTICOSTERone ACETATe (DCA) injections. "Steroid escape" was attained on the third day. PAH was infused throughout; Subject R.S.

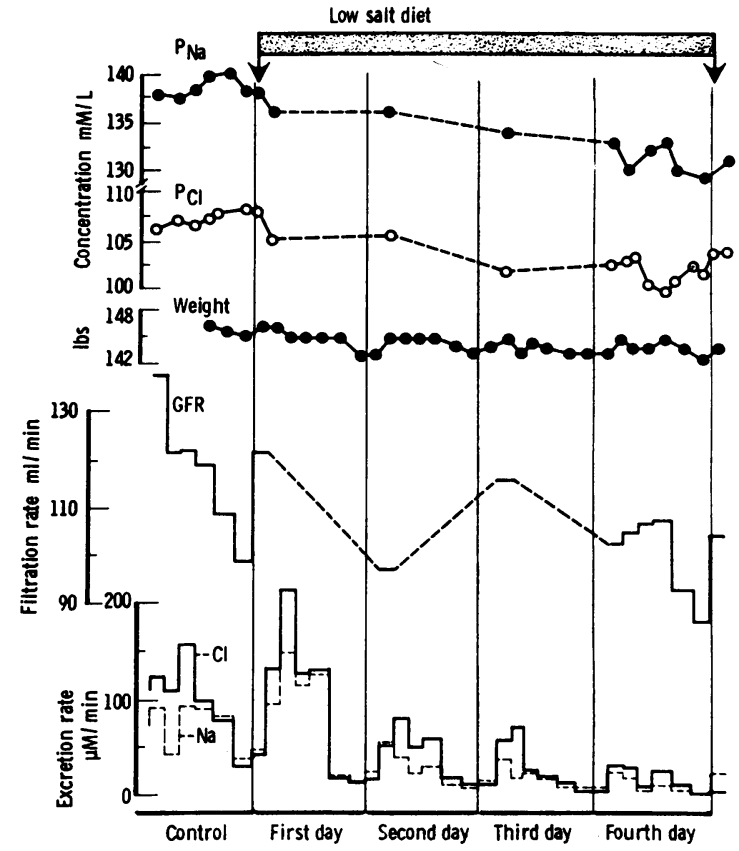

Fig. 4. Diurnal cycle of filtration rate and soDIUM AND CHLORIDE EXCRETION BEFORE AND ON THE FOURTH DAY OF A LOW SALT DIET. Filtration rate was measured briefly each morning of the first 3 days on the low salt diet. PAH was not infused; Subject R.S.

lar filtration before and during chronic water loading are shown in Figure 2. On the morning of the first experimental day the subject received the first of repeated injections of vasopressin (Pitressin tannate in oil) and drank $4 \mathrm{~L}$ of water over the next several hours. The approximately 10 -pound weight increase was thereafter maintained nearly constant by appropriate adjustment of fluid intake.

During the first day mean filtration rate was increased (117, compared with $102 \mathrm{ml}$ per minute during the control day). Chloride excretion decreased markedly, while sodium was little changed. Much, if not most. of the decrease in $\mathrm{Cl}$ excretion seems attributable, provisionally, to the decrease in plasma $\mathrm{Cl}$ concentration. Although some of the excess of sodium over chloride is attributable to $p$-aminohippurate, it seems more likely that a considerable fraction of the sodium excretion is obligated by bicarbonate, as has been reported by Wrong ${ }^{3}(47)$. The mechanism of alkaline urine

${ }^{3}$ Also reported by Wrong and present in our experimental data is a decrease in potassium excretion at this time, an observation of interest in view of the simultaneous formation of an alkaline urine. 


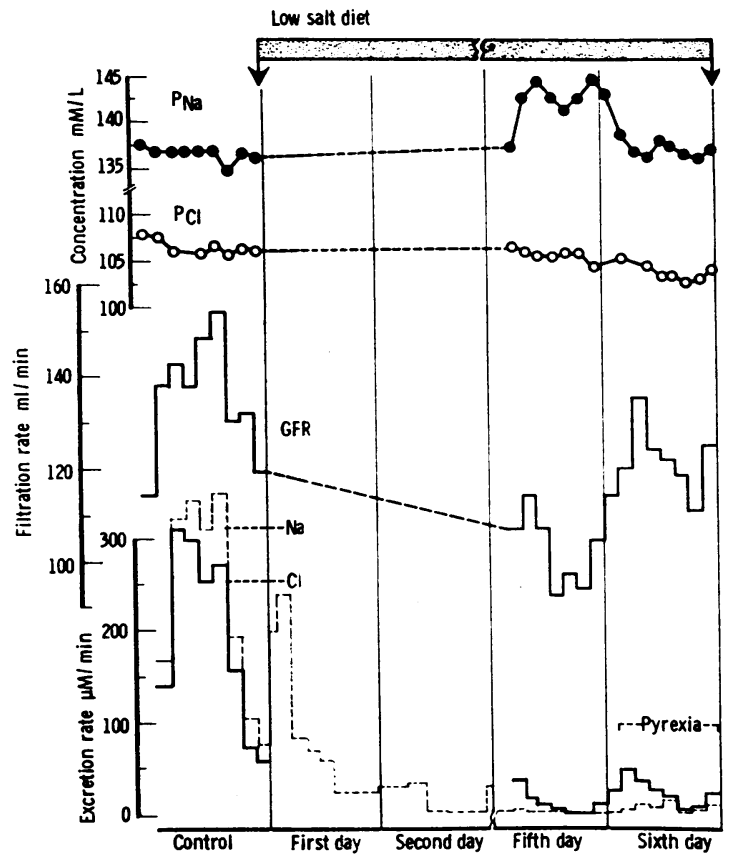

Fig. 5. Diurnal CyCle OF Filtration RATE AND SODIUM AND CHLORIDE EXCRETION BEFORE AND ON THE FIFTH AND SIXTh DAYS OF A LOW SALT DIET. Excretion of sodium, alone, was measured during the first 4 days on the low salt diet. The third and fourth days, exhibiting progressively diminishing excretion but with diurnal patterns similar to that of the second day, have heen omitted as noncontributory. Subject L.W.: age 43; wt $75 \mathrm{~kg}$ : ht $179 \mathrm{~cm}$.

formation under these circumstances is unknown. The filtration rate cycle correlates well with the sodium but not with the chloride cycle.

During the second and third experimental days, $\mathrm{Na}$ and $\mathrm{Cl}$ excretion and glomerular filtration rate
(GFR) rose progressively, the latter to 138 and $167 \mathrm{ml}$ per minute, compared with 102 and 117 in the control and first experimental days (Table I). The filtration rate cycle on the second day was well preserved, and its amplitude apepars increased, similar to that observed during saline infusion. Sodium and chloride excretion exceeded intake, plasma concentrations declined, weight also decreased slightly from its maximum, and frank symptoms of water intoxication ensued. Difficulty in voiding, progressing to complete retention, rendered all individual clearance periods on the third day unreliable, although the 24-hour mean value is probably accurate.

Diurnal cycle during steroidal salt retention. The diurnal cycle of $\mathrm{NaCl}$ excretion and glomerular filtration before and during salt retention induced by deoxycorticosterone acetate (DCA) injection is shown in Figure 3. $\mathrm{Na}$ and $\mathrm{Cl}$ excretion decreased during the first day of DCA injections but increased progressively thereafter to reach the control rate of excretion (steroid escape) on the third day. The general contour of the diurnal excretory curve appears to be little altered by DCA, as noted also by Stanbury and Thomson (12). The filtration rate cycle was not evidently affected on the first day, but both the mean values and possibly, also, the amplitude, increased progressively on the second and third days. Plasma concentrations showed little change.

Diurnal cycle during salt depletion. The diurnal cycles of $\mathrm{NaCl}$ excretion and glomerular filtration before and after several days on low salt diets are shown in Figure 4 and 5. Salt-free inulin was

TABLE I

Mean diurnal inulin clearance and 24-hour chloride excretion before and during alteration in body fluid balance

\begin{tabular}{|c|c|c|c|c|c|c|c|c|}
\hline \multirow[b]{2}{*}{ Protocol } & \multicolumn{4}{|c|}{ Inulin clearance $(\mathrm{ml} / \mathrm{min})$} & \multicolumn{4}{|c|}{ Chloride excretion (mmoles/24 hrs) } \\
\hline & $\begin{array}{l}\text { Control } \\
\text { day }\end{array}$ & Day 1 & Day 2 & $\begin{array}{l}\text { Last } \\
\text { day* }\end{array}$ & $\begin{array}{c}\text { Control } \\
\text { day }\end{array}$ & Day 1 & Day 2 & $\begin{array}{l}\text { Last } \\
\text { day* }\end{array}$ \\
\hline $\begin{array}{l}\text { Saline infusion (Figure } 1 \\
\text { Water loading (Figure } 2 \\
\text { Salt retention (Figure } 3 \text { ) } \\
\text { l.ow salt diet (Figure 4) } \\
\text { Low salt diet (Figure 5) }\end{array}$ & $\begin{array}{l}128.2 \\
101.8 \dagger \\
119.7 \\
116.5 \\
137.8\end{array}$ & $\begin{array}{l}131.7 \dagger \\
117.3 \\
123.2\end{array}$ & $\begin{array}{l}135.6 \\
138.5 \\
138.1\end{array}$ & $\begin{array}{l}145.0 \\
166.6 \\
139.8+ \\
99.8 \\
112.5\end{array}$ & $\begin{array}{l}215 \\
215 \\
238 \\
135 \\
280\end{array}$ & $\begin{array}{r}344 \\
85 \\
95\end{array}$ & $\begin{array}{l}578 \\
296 \\
174\end{array}$ & $\begin{array}{l}569 \\
420 \\
470+ \\
26 \\
28\end{array}$ \\
\hline
\end{tabular}

Low salt diet (Figure 5)

* Third day in experiments, Figures 1-3; fourth day in experiment, Figure 4 ; average of fifth and sixth dars in experiment, Figure 5.

† Interpolated values are substituted for technically unsatisfactory clearance measurements in calculating a 24 -hour mean value on these days.

$\ddagger$ Unmeasured nighttime periods are assumed to follow the contour of the preceding cycle in calculating 24-hour mean clearance and excretion values on this day. 


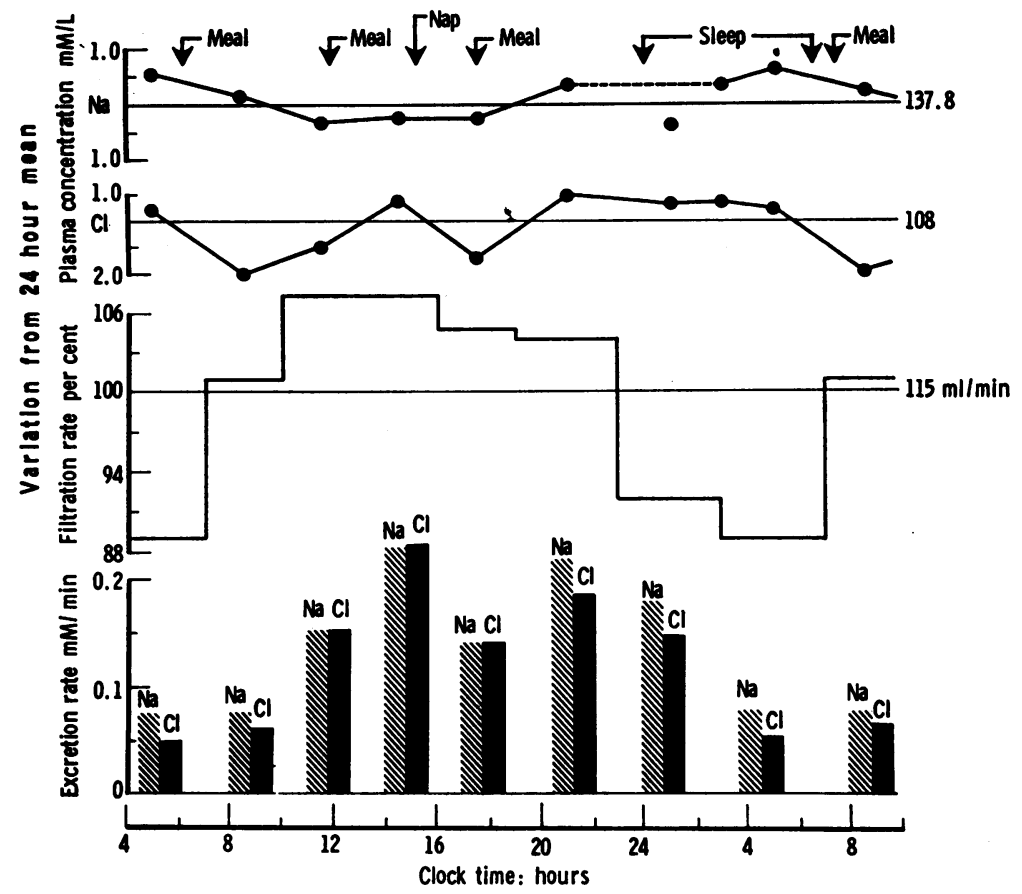

Fig. 6. Average diurnal cycle of filtration rate, sodium and ChloRIDE EXCRETION, AND PLASMA SODIUM AND CHLORIDE CONCENTRATIONS DURING CONTROL DAYS ON UNRESTRICTEd DIET IN SubJect R.S. Filtration rate is represented as per cent variation of each period from the 24-hour mean of $115 \mathrm{ml}$ per minute. Plasma sodium and chloride concentrations are represented as concentration differences of each period from the 24-hour means of 137.8 and 108 mmoles per L, respectively. Amplitudes of filtration rate and plasma sodium and chloride cycles are 21 per cent and 1 and 3 mmoles per L.

not available for one of these studies, with the result that, in Experiment 4 (Figure 4), the subject received nearly as much salt during the brief measurements of inulin clearance on the first, second, and third low salt days as he received from his diet. About $1.5 \mathrm{~g}$ of salt was contained in the 24-hour infusion on the fourth day. Inulin solutions employed during the second study (Figure 5) were salt-free. Although both the minimal values and the amplitude of the $\mathrm{NaCl}$ excretory cycles were decreased as expected, it is of additional interest that the duration of the daytime peak tended to decrease, with a corresponding widening of the nocturnal minimum.

The 24-hour mean values of glomerular filtration rate were decreased on the low salt diets from 116 to 100 and from 138 to $113 \mathrm{ml}$ per minute in Subjects R.S. and L.W., respectively (Table I). The diurnal cycle of filtration rate was preserved, although the mean amplitude of both subjects (20 per cent) may have been somewhat decreased. The data are insufficient to determine whether the contour of the filtration rate cycle was altered significantly.

\section{DISCUSSION}

A provisional description of the diurnal cycle of filtration rate in normal man can be obtained from these experiments. Filtration rate is lowest near the end of the sleeping period. It increases rapidly after awakening and, in normally hydrated individuals, remains at generally elevated levels until the beginning of the sleep period. The probable amplitude of 25 and perhaps 30 per cent of the mean value is much greater than that suggested by previous studies. Alterations in the cycle occur in normal individuals with altered body fluid balance. In subjects with expanded fluid volume as the result of saline infusion, water loading under the influence of vasopressin, or salt retention 
under the influence of deoxycorticosterone, the amplitude frequently appears to be increased primarily as the result of an increase in the daytime maximum. In addition, the daytime peak tends to extend well into the sleep period. Opposite changes were observed in the subjects on a low salt diet, in whom a probable lowering of the nighttime minimum, together with a somewhat greater lowering of the daytime maximum and some decrease in amplitude, occurred. The data are insufficient to draw conclusions concerning changes in the contour of the cycle during depletion. It is of interest that a near normal cycle is maintained in the normal subject during severe salt retention, while the cycle is apparently reversed in the saltretaining patient with heart or liver disease $(25$, 27).

Pertinent to interpretation of salt excretion studies is the observation that, although the 24hour mean inulin clearance is increased during salt or water loading and decreased during salt deprivation, the diurnal cycles in all states often overlap one another. Hence, by inadvertently selecting the appropriate phase of the cycle in which to make brief measurements of filtration rate, it is possible to obtain the same value of filtration rate under widely varying conditions of fluid balance, or else varying values under constant conditions of balance. Particularly during the morning hours, random measurements of filtration rate cannot be expected to correlate satisfactorily with 24hour measurements of sodium chloride excretion.

Correlation between filtration rate and chloride excretion in Subject R.S., ${ }^{4}$ during individual clearance periods in several diurnal cycles on a routine diet, is illustrated in Figure 7. The solid line is the theoretical but semiempirical relationship between filtration rate and chloride excretion as deduced from studies on the dog and transposed to man (23). The broken lines represent the uncertainty limits (2 SD, or 10 per cent) to the measurement of filtration rate. Details of the derivation of the theoretical curve are beyond the scope of this paper, but are based upon attribution to a proximal chloride transport process of a proportionality coefficient to filtration rate of 0.085 mmoles per $\mathrm{ml}$, attribution to a distal chloride transport process of a maximal transport rate of

${ }^{4}$ Clearance data on Subjects K.B. and L.W. are insufficient for an analysis of this form.

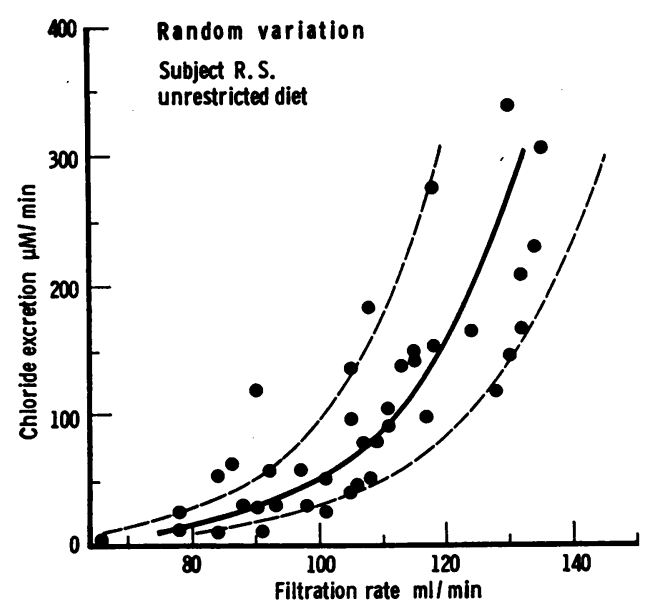

Fig. 7. Correlation between filtration Rate AND CHLORIDE EXCRETION DURING SEVERAL DIURNAL CYCLES IN Subject R.S. on UNRESTRICTEd Diet. Each point represents an individual clearance period. The solid curve represents a hypothetical relationship between filtration rate and chloride excretion, as described in the text. The broken curves lie 2 SD (10 per cent) of estimated error of measurement of filtration from the mean value.

4.0 mmoles per minute per $1.73 \mathrm{~m}^{2}$ and a titration splay similar to that for glucose, and existence of a filtrate chloride concentration of 107 mmoles per L. The general curve for an average man (23) is adjusted to Subject R.S. by multiplying the filtration rate scale by 0.83 . All terms in the equations, including titration splay and plasma concentration, are considered significant parameters. Since the two-variable system (excretion against filtration in Figure 7) does not provide for the operation on excretion of changing plasma concentration, recourse was had to the theoretical equations. These predicted that a 1.0 mmole per $\mathrm{L}$ change in plasma chloride concentration should be equivalent to a 3.5 to 4.5 $\mathrm{ml}$ per minute change in filtration rate over the range of filtration rate values observed. Accordingly, an observed filtration rate value was "corrected" 5 if, in that clearance period, plasma chloride concentration varied from the mean concentration for all control days. The "corrected" filtration rate values are plotted in Figure 7 . The correction in either direction seldom exceeded 8 or $9 \mathrm{ml}$ per minute, however, and for most of the data was less than $5 \mathrm{ml}$ per minute. The fit of the

\footnotetext{
$5 \mathrm{GFR}_{\mathrm{cor}}=\mathrm{GFR}_{\mathrm{obs}}+\mathrm{F}\left(\mathrm{P}_{\mathrm{cl}}-\overline{\mathrm{P}}_{\mathrm{Cl}}\right)$, where $\mathrm{F}$ is the factor converting concentration units to filtration units, averaging, in these studies, $4 \mathrm{ml}$ per minute.
} 
data to the theoretical curve is better than is warranted by the many uncertainties involved in the measurement of inulin clearance, the extension to man of constants derived under acute loading conditions on the dog, the assumption that glucose and chloride transport should have a similar titration splay, and the assumption that the relationships between plasma concentration and excretion, derived for high concentrations, obtain equally in the normal or subnormal range. It may be confidently predicted that other studies will exhibit a correlation between theory and experiment more realistically in accord with sources of error in measurements of this nature.

In view of the results of previous studies which have demonstrated a general decrease in filtration rate during dehydration or salt deprivation and an increase in filtration rate during fluid loading in normal subjects, a major objective of these experiments was determination of the time of onset and rate of change of filtration rate. and correlation of these changes with changes in $\mathrm{NaCl}$ excretion. In the three experiments associated with body fluid expansion, a major increase in filtration occurred on the second day of loading and, in each instance, was correlated with a marked increase in excretion above the level of the first loading day (Table I). In the two experiments on salt deprivation, filtration rate is clearly depressed below control levels by the fourth day and, as suggested by brief measurements, may well be depressed by the third or second day. It may be concluded provisionally, therefore, that changes in filtration rate closely parallel changes in salt excretion attendant upon alterations in fluid balance in healthy subjects.

Correlation between $\mathrm{NaCl}$ excretion and filtration rate changes do not imply that excretion normally is governed by filtration rate changes alone in an otherwise rigid filtration-reabsorption system. A contribution to excretion of filtrate concentration changes, at least within wide limits, is indicated by the effects of hypertonic saline infusions and, in the present studies, by the decrease in chloride excretion immediately after water loading (Figure 2). Susceptibility of the $\mathrm{NaCl}$ transport system to stimulation from various steroids is well documented (23) and is illustrated in Figure 8. Filtration rate in this subject must be roughly $25 \mathrm{ml}$ per minute greater during DCA administration than in its absence, to

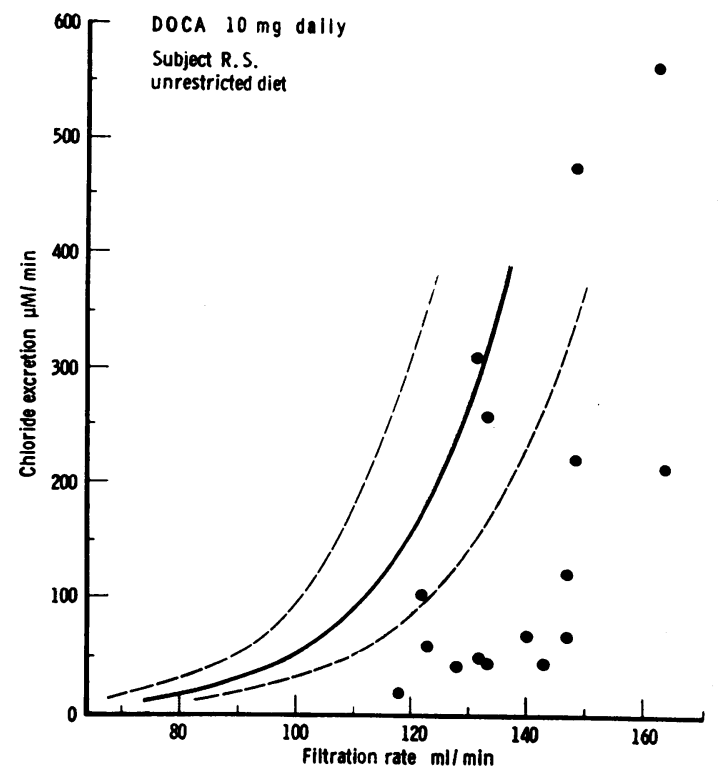

Fig. 8. CoRrelation BetweEn filtration RATE AND CHLORIDE EXCRETION DURING DEOXYCORTICOSTERONE ACEtate (DCA) administration in Subject R.S. (FigURE 3). The hypothetical curves relating excretion and filtration in the untreated state (Figure 7) are reproduced for reference. Chloride excretion rates equivalent to those observed in the untreated state are attained during DCA administration only at higher filtration rates.

maintain a constant excretion rate of 0.1 mmole per minute. The simplest description of the steroid effect, within the context of the aforementioned hypothetical transport system, is a marked decrease in the titration splay, together with a possible small increase in transport maximum, of the distal $\mathrm{NaCl}$ transport system. Filtration rate nevertheless would seem to account almost entirely for most short-term changes in $\mathrm{NaCl}$ excretion, such as are observed during the normal diurnal cycle and early after acute blood volume contraction and related stresses (23). Absence of important contributions to the $\mathrm{NaCl}$ excretory cycle from adrenocortical function is suggested by occurrence of near normal cycles in hypoadrenal patients $(8,20,48,49)$, together with absence of significant diurnal variations in aldosterone excretion in quiescent subjects (50-55). Rising filtration rate may well be responsible, also, for the phenomenon of steroid escape and for the delayed natriuresis which follows chronic water loading.

The mechanisms that determine the diurnal 
rhythm of filtration rate and, more remotely, the changes in this rhythm under various loading conditions are unknown. That a rhythm of the magnitude observed in man is not a necessary aspect of renal function is demonstrated by the apparent absence of a significant rhythm in quiet, fasting dogs (56). The extent of pre- as compared with postglomerular vascular resistance changes that may occur during the cycle and which, therefore, constitute the immediate cause of the changes in filtration will require a more detailed analysis of simultaneous changes in renal plasma flow. Proof that the rhythm is not dependent upon the renal nerves is lacking, but no evidence of vasodilator nerves or of neurogenically controlled hemodynamic changes in unstressed animals has been discovered. By exclusion, we must postulate the existence of one or more humoral transmitters, the secretions of which are dependent. ultimately, upon a "volume receptor." No recognized hormone fulfills this function. To designate this hypothetical humoral system, which has as a major function the control of filtration rate, the term. "glomerulokinin" has been proposed elsewhere (57). In this view a humoral system controlling aldosterone secretion and a humoral system controlling glomerular filtration are two afferent arms of a reflex system controlling extracellular or vascular volumes, while the fluid volume control system is but a portion of a more general and presumably integrated system which preserves the integrity of the circulation.

\section{SUMMARY}

Filtration rate (inulin clearance) and the excretion rates and plasma concentrations of sodium and chloride were measured continuously through the diurnal cycle in three quiescent, healthy, male subjects.

The normal diurnal cycle of filtration rate under control conditions exhibits a characteristic nocturnal minimum and diurnal maximum with an amplitude of 25 and perhaps as much as 30 per cent of the mean.

Under fluid loading by saline infusion, chronic water loading supported by vasopressin injections, or salt retention induced by deoxycorticosterone acetate injections, the diurnal filtration cycle shows a tendency to a widening of the daytime maximum and a possible increase in amplitude.
Under fluid depletion attending consumption of a low salt diet, the filtration cycle shows a tendency to a decrease in amplitude and in mean level, but whether the daytime maximum is narrowed, parallel with the simultaneous narrowing of the diurnal peak in chloride excretion, cannot be determined from the available data.

In the present experiments significant changes in the 24-hour mean filtration rate level occurred relatively early, increasing on the second day of the fluid loading studies, and decreasing by the fourth day on the low salt diets.

A close quantitative correlation between filtration rate and chloride excretion is evident during the normal or control diurnal cycle of excretion, while a close qualitative correlation between excretion and filtration is evident during the excretion changes attendant upon fluid loading or depletion. A rising filtration rate is proposed as the principal cause of the delayed natriuresis occurring during sustained water loading and of the phenomenon of "steroid escape."

An unknown humoral system, provisionally termed "glomerulokinin," may determine the normal diurnal cycle of filtration rate and the changes in the cycle attendant upon alteration in body salt or fluid balance.

\section{REFERENCES}

1. Völker, H. UUber die tagesperiodischen Schwankungen einiger Lebensvorgänge des Menschen. Pflüg. Arch. ges. Physiol. 1927, 215, 43.

2. Campbell, J. A., and Webster, T. A. Day and night urine during complete rest, laboratory routine, light muscular work and oxygen administration. Biochem. J. 1921, 15, 660.

3. Kleitman, N. Studies on the physiology of sleep. I. The effects of prolonged sleeplessness on man. Amer. J. Physiol. 1923, 66, 67.

4. Simpson, G. E. Diurnal variations in the rate of urine excretion for two hour intervals: Some associated factors. J. biol. Chem. 1924, 59, 107.

5. Simpson, G. E. The effect of sleep on urinary chlorides and $\mathrm{pH}$. J. biol. Chem. 1926, 67, 505.

6. Simpson, G. E. Changes in the composition of urine brought about by sleep and other factors. J. biol. Chem. 1929, 84, 393.

7. Norn, M. Untersuchungen über das Verhalten des Kaliums im Organismus. II. Uber Schwankungen der Kalium-, Natrium- und Chloridausscheidung durch die Niere im Laufe des Tages. Skand. Arch. Physiol. 1929, 55, 184.

8. Manchester, R. C. The diurnal rhythm in water and mineral exchange. J. clin. Invest. 1933, 12, 995. 
9. Barbour, A., Bull, G. M., Evans, B. M., HughesJones, N. C., and Logothetopoulos, J. The effect of breathing 5 to $7 \%$ carbon dioxide on urine flow and mineral excretion. Clin. Sci. 1953, 12, 1.

10. Borst, J. G. G., and de Vries, L. A. The three types of "natural" diuresis. Lancet 1950, 259, 1.

11. Gerritzen, F. Der 24-Stunden-Rhythmus der Chlorausscheidung. Pflüg. Arch. ges. Physiol. 1937, 238, 483.

12. Stanbury, S. W., and Thomson, A. E. Diurnal variations in electrolyte excretion. Clin. Sci. 1951, 10, 267.

13. Azérad, E., Lestradet, H., Reinberg, A., and Gatha, $\mathrm{J}$. Variations nycthémèrales de l'élimination urinaire du potassium, du sodium et du chlore chez l'homme normal. Ann. Méd. 1953, 54, 431.

14. Lewis, P. R., and Lobban, M. C. Patterns of electrolyte excretion in human subjects during a prolonged period of life on a 22-hour day. J. Physiol. (Lond.) 1956, 133, 670.

15. Lewis, P. R., and Lobban, M. C. The effects of prolonged periods of life on abnormal time routines upon excretory rhythms in human subjects. Quart. J. exp. Physiol. 1957, 42, 356.

16. Lewis, P. R., and Lobban, M. C. Dissociation of diurnal rhythms in human subjects living on abnormal time routines. Quart. J. exp. Physiol. 1957, 42, 371.

17. Payne, R. W., and de Wardener, H. E. Reversal of urinary diurnal rhythm following head injury. Lancet 1958, 1, 1098.

18. Doe, R. P., Vennes, J. A., and Flink, E. B. Diurnal variation of 17-hydroxycorticosteroids, sodium, potassium, magnesium and creatinine in normal subjects and in cases of treated adrenal insufficiency and Cushing's syndrome. J. clin. Endocr. 1960, 20, 253.

19. Campbell, J. A., and Webster, T. A. Note on urinary tides and excretory rhythm. Biochem. J. 1922, 16, 507.

20. Garrod, O., and Burston, R. A. The diuretic response to ingested water in Addison's disease and panhypopituitarism and the effect of cortisone thereon. Clin. Sci. 1952, 11, 113.

21. Wrong, O. The volume control of body-fluids. Brit. med. Bull. 1957, 13, 10.

22. Mills, J. N., and Stanbury, S. W. Intrinsic diurnal rhythm in urinary electrolyte output. J. Physiol. (Lond.) 1951, 115, 18P.

23. Wesson, L. G., Jr. Glomerular and tubular factors in the renal excretion of sodium chloride. Medicine (Baltimore) 1957, 36, 281.

24. Sirota, J. H., Baldwin, D. S., and Villarreal, $H$. Diurnal variations of renal function in man. J. clin. Invest. 1950, 29, 187.

25. Baldwin, D. S., Sirota, J. H., and Villarreal, H. Diurnal variations of renal function in congestive heart failure. Proc. Soc. exp. Biol. (N. Y.) 1950, 74,578 .
26. Fejfar, Z., and Brod, J. The excretion of chlorides in patients with heart failure. Quart. J. Med. 1950, n.s. 19, 221.

27. Jones, R. A., McDonald, G. O., and Last, J. H. Reversal of diurnal variation in renal function in cases of cirrhosis with ascites. J. clin. Invest. 1952, 31, 326.

28. Markley, K., Bocanegra, M., Morales, G., and Chiappori, M. Oral sodium loading in normal individuals. J. clin. Invest. 1957, 36, 303.

29. Leaf, A., Bartter, F. C., Santos, R. F., and Wrong, O. Evidence in man that urinary electrolyte loss induced by Pitressin is a function of water retention. J. clin. Invest. 1953, 32, 868.

30. Weston, R. E., Grossman, J., Essig, A., Isaacs, M. C., Hanenson, I. B., and Horowitz, H. B. Homeostatic regulation of body fluid volume in nonedematous subjects. Metabolim 1960, 9, 157.

31. McCance, R. A., and Widdowson, E. M. The secretion of urine in man during experimental salt deficiency. J. Physiol. (Lond.) 1937, 91, 222.

32. Black, D. A. K., McCance, R. A., and Young, W. F. Function of the kidney in dehydration. Nature (Lond.) 1942, 150, 461.

33. Black, D. A. K., Platt, R., and Stanbury, S. W. Regulation of sodium excretion in normal and salt-depleted subjects. Clin. Sci. 1950, 9, 205.

34. Chasis, H., Goldring, W., Breed, E. S., Schreiner, G. E., and Bolomey, A. A. Salt and protein restriction: Effects on blood pressure and renal hemodynamics in hypertensive patients. J. Amer. med. Ass. 1950, 142, 711.

35. Weston, R. E., Hellman, L., Escher, D. J. W., Edelman, I. S., Grossman, J., and Leiter, L. Studies on the influence of the low sodium cardiac diet and the Kempner regimen on renal hemodynamics and electrolyte excretion in hypertensive subjects. J. clin. Invest. 1950, 29, 639.

36. Wiggins, W. S., Manry, C. H., Lyons, R. H., and Pitts, R. F. The effect of salt loading and salt depletion on renal function and electrolyte excretion in man. Circulation 1951, 3, 275.

37. Zierler, K. L., and Lilienthal, J. L., Jr. Sodium loss in man induced by desoxycorticosterone acetate; study in subject with myotonic dystrophy. Amer. J. Med. 1948, 4, 186.

38. Luft, R., and Sjögren, B. The significance of renal function for the effect of desoxycorticosterone acetate (DCA) in Addison's disease. Acta endocr. (Kbh.) 1949, 2, 365.

39. Luft, R., and Sjögren, B. The effect of desoxycorticosterone acetate (DCA) and sodium chloride on blood pressure and renal function. Acta endocr. (Kbh.) 1949, 3, 56.

40. Alexander, J. D., Pellegrino, E. D., Farber, S. J., and Earle, D. P. Observations on the relation of renal function changes to the electrolyte and glucosuric effects of ACTH in man. Endocrinology 1951, 49, 136. 
41. Pechet, M. M., Bowers, B., and Bartter, F. C. Metabolic studies with a new series of 1,4-diene steroids. II. Effects in normal subjects of prednisone, prednisolone, and $9 \alpha$-fluoroprednisolone. J. clin. Invest. 1959, 38, 691.

42. Baldwin, D. S., Schreiner, G. E., Breed, E. S., Wesson, L. G., Jr., and Maxwell, M. H. Depression of apparent P-aminohippurate extraction ratio by glucose. J. clin. Invest. 1950, 29, 614.

43. Co Tui, M., Schrift, H., McCloskey, K. L., and Yates, A. L. Filtration studies on pyrogenic inulin. Proc. Soc. exp. Biol. (N. Y.) 1937, 36, 227.

44. Roe, J. H., Epstein, J. H., and Goldstein, N. P. A photometric method for the determination of inulin in plasma and urine. J. biol. Chem. 1949, 178, 839.

45. Schreiner, G. E. Determinations of inulin by means of resorcinol. Proc. Soc. exp. Biol. (N. Y.) 1950, 74, 117.

46. Van Slyke, D. D., and Hiller, A. Application of Sendroy's iodometric chloride titration to protein-containing fluids. J. biol. Chem. 1947, 167, 107.

47. Wrong, O. The relationship between water retention and electrolyte excretion following administration of antidiuretic hormone. Clin. Sci. 1956, 15, 401.

48. Levy, M. S., Power, M. H., and Kepler, E. J. The specificity of the "water test" as a diagnostic procedure in Addison's disease. J. clin. Endocr. 1946, 6, 607.
49. Rosenbaum, J. D., Papper, S., and Ashley, M. M. Variations in renal excretion of sodium independent of change in adrenocortical hormone dosage in patients with Addison's disease. J. clin. Endocr. 1955, 15, 1459.

50. Venning, E. H., Dyrenfurth, I., and Giroud, C. Diurnal variation in excretion of a sodium-retaining substance. Fed. Proc. 1955, 14, 297.

51. Venning, E. H., Dyrenfurth, I., and Giroud, C. J. P. Aldosterone excretion in healthy persons. J. clin. Endocr. 1956, 16, 1326.

52. Luetscher, J. A., Jr., and Curtis, R. H. Symposium on biochemistry of disease; observations on aldosterone in human urine. Fed. Proc. 1955, 14, 746.

53. Muller, A. F., Riondel, A. M., and Manning, E. L. L'excrétion de l'aldostérone au cours du nycthémère. Helv. med. Acta 1957, 24, 463.

54. Muller, A. F., Manning, E. L., and Riondel, A. M. Diurnal variation of aldosterone related to position and activity in normal subjects and patients with pituitary insufficiency in Aldosterone. New York, Little, Brown, 1958, 111.

55. Bartter, F. C., Biglieri, E. G., Pronove, P. and Delea, C. S. Effect of changes in intravascular volume on aldosterone secretion in man in Aldosterone. New York, Little, Brown, 1958, 100.

56. Dossetor, J. B. Personal communication.

57. Wesson, L. G., Jr. Physiology of the Kidney. Handbuch der Urologie, vol. II. Heidelberg, Springer Verlag. In press.

\section{SPECIAL NOTICE TO SUBSCRIBERS}

Post Offices will no longer forward the Journal when you move.

Please notify The Journal of Clinical Investigation, Business Office, 333 Cedar Street, New Haven 11, Conn., at once when you have a change of address, and do not omit the zone number if there is one. 